\title{
REGULATION OF WELL SPACING IN OIL AND GAS PRODUCTION
}

\author{
ROWLAND HARRISON*
}

The common law did not enforce any particular pattern of spacing of wells on early drillers for oil and gas. The result was reduced production at greatly increased cost. The author traces the development of spacing legislation in the United States and Canada, particularly in Texas and Alberta, and summarizes the considerations which should determine the most profitable spacing policy for all parties concerned. After exploring the use of unitization in petroleum production, it is concluded that compulsory unitization elminates the need for spacing legislation as the objectives of such legislation will have already been achieved.

\section{INTRODUCTION}

"The more wells, the more oil" was the mistaken belief which contributed probably more than any other single factor to the deplorable waste which was characteristic of development in the early history of the petroleum industry. Adherence to its fallacy, combined with the urgent need to develop under the Rule of Capture and offset drilling obligations, resulted in an extraordinarily excessive and wasteful number of wells being drilled. No restrictions were imposed by the common law. As stated in Brown v. Humble Oil and Refining Co.: ${ }^{1}$

The common law recognizes no well spacing regulations. At common law the

landowner can drill an unlimited number of wells for oil and gas upon his

land. The adjoining landowner cannot complain if wells are drilled near his

boundary line. Under this rule the only way the landowner can protect himself is to drill offset wells.

Indeed, this doctrine encouraged the drilling of further wells with the consequent waste due to immediate over-production and long-term depletion of reservoir energy. ${ }^{2}$ Not only this; close spacing increased the danger of spread of fire or a blowout. Thus, apart from the question of waste, there was a safety factor to be considered and, in view of the attitude of the common law, legislative action was demanded.

Thus, since the introduction of the first spacing regulation in 1919 in Texas, ${ }^{3}$ well spacing has been a feature of regulation of the petroleum industry. The approaches have varied in the light of improving technology and increased knowledge of the characteristics of oil and gas reservoirs. However, no matter what the particular requirements of any statute or regulation, the principles that reservoir energy be conserved, safety hazards be reduced and the property rights of owners be protected against the full consequences of the Rule of Capture by requiring minimum spacing between wells have stood. Some statutes in the U.S. recite this principle as one of their objects. ${ }^{4}$

The term "well spacing" is used throughout the legislation (and in this article) to designate the distance between wells or the amount of surface area attributable to each well. The object broadly is to elim-

-LL.B. (Tasmania), Barrister and Solicitor of the Supreme Court of Tasmania: Sessional Instructor, Faculty of Law, The University of Alberta. The writer gratefully acknowledges the counsel of Dr. A. R. Thompson, Professor, Faculty of Law, University of edges the counsel of Dr. A. R. Thompson, Professor, Faculty of Law,

British Columbia, under whose

2 "The operators endeavoured to 'git there fustest with the mostest' wells." Raymond M. Myers, Spacing, Pooling and Field-Wide Unitization, (1947) 18 Miss. L.J. 267.

3 Infra, page 361.

4 W. L. Summers. The Law of Oil and Gas (1954) Ch. 5, \$83 et seq. 
inate the unnecessary well, i.e., a well that will fail to increase the ultimate recovery from a field by an amount sufficient to return the investment, plus the cost of operations and royalties, and plus a reasonable profit." Modern petroleum technology indicates that one well could drain an entire geologically simple reservoir if the well were located ideally and if time and economics were ignored. ${ }^{\circ}$ Obviously time and economics cannot be ignored and so the optimum spacing is concluded to be "the maximum number of reservoir acres that would be economically and effectively drained by one well within a reasonable period of time." Some statutes in the U.S. define drilling units in terms similar to these ${ }^{8}$ but, as will be seen, a further factor must be taken into account by legislatures and regulatory agencies. This is that proper protection must be given to the proprietary rights of mineral owners, so that the "optimum spacing", as defined, may not be the spacing which is required by law. Conservation measures have to be balanced to some extent against property interests although the requirements of this policy have been satisfied to some extent by provision for voluntary and compulsory pooling.

A general examination of the history of spacing in the U.S. is proposed so that the position in Alberta can be seen in light of the experience, requirements and problems of regulation there. The vast body of U.S. law on spacing has arisen mainly in litigation involving the spacing regulations of Texas which are therefore dealt with separately to illustrate the problems involved in protection of property rights.

It is proposed then to discuss the role of spacing in the overall picture of conservation measures. Pooling is considered in the following section of the article because of its unseverable connection with spacing requirements. Many writers have advocated unitization of oil fields as the only proper method of development. This subject is therefore considered as, in some forms at least, it renders spacing requirements unnecessary. The remainder of the article is devoted to a history of spacing in Alberta, and the present requirements under The Oil and Gas Conservation Act. ${ }^{\circ}$ Finally, some consideration will be given to future trends in spacing regulation.

\section{HISTORY IN THE U.S.}

Three factors contributed to the dense development of oil production in the early history of the U.S. petroleum industry. They were:

(i) almost total ignorance of the nature of oil and gas reservoirs;

(ii) adherence to the Rule of Capture with the consequent introduction of off-set obligations;

(iii) the increased demand for crude oil in the period from 1900 to 1925.

These factors operated severally and jointly to cause vast numbers of unnecessary wells to be drilled.

\footnotetext{
5. Allen King, Pooling and Unitization of Oil and Gas Leases, (1948) 46 Mich L. Rev. 311 at 312

Interstate Oil Compact Commission (I.O.C.C.) A Study of Conservation of Oil and

Gas in the U.S. (1964), 57.

Id.

8 Myers, supra, n. 4 , at 267.
}

S S.A. 1969 , c. 83 . 


\section{Early knowledge of reservoirs}

It was not appreciated early that dense drilling depleted reservoir energy with a consequent reduction in the quantity of oil ultimately recovered. In fact, as mentioned in introducing this paper, producers firmly believed that the more wells they drilled, the more oil they would recover. And recover more oil they did, but only for a shorter time than had they been aware of what was happening in the reservoir and altered their practices accordingly. Appearances on the surface were that more oil was won by drilling more wells. In this area, petroleum engineering and technology have developed from the theory that a direct relationship existed between the number of wells drilled and the amount of oil recovered, to the present state of knowledge that ultimate recovery is largely independent of well spacing except insofar as high density drilling wastes reservoir energy. In other words, the early belief of oil producers was precisely contrary to what in fact happens as a result of drilling further wells.

\section{The Rule of Capture}

The Rule of Capture by its provision that oil and gas are owned by the person reducing them to possession also contributed to the excessive drilling of wells. Although general knowledge of reservoir characteristics was limited, it was realized early that oil and gas were fugacious and moved in reservoirs when pressure variations occurred so that a well drilled on A's land would drain the oil under B's land. In the absence of statutory intervention, B's remedy was to drill his own well and recover the oil or gas for himself. Lessees were required early to drill wells on property adjacent to discoveries under the provisions of off-set clauses in their leases. However, as if this requirement did not in itself lead to the drilling of a considerable number of unnecessary wells, A soon realized that B's well was reducing the amount of oil and gas which was being produced through his well. A's remedy in this instance was obvious to him. He simply had to drill more wells than $B$, and as close to B's boundary as he could. Then, naturally enough in light of the then knowledge of reservoirs, B matched his neighbour's conduct as he had done in the first instance. As one writer has commented: ${ }^{10}$

A pattern of behaviour developed wherein no owner in a pool was free to act; each was tied to a principle of matching the conduct of the other. It became an accepted principle that so long as each offsetting owner mocked and duplicated the behaviour of the other, each would bring about mutual protection against drainage and each would properly share the oil in the common pool. It appeared that way on the surface.

\section{The increased demand}

As if the fallacy that more wells produced more oil and the pressure to develop under the Rule of Capture were not alone enough to cause excessive drilling, the demand for crude oil increased dramatically in the period from 1900 to $1925 .{ }^{12}$ This was due largely to the invention of the internal combustion engine and the resulting demand for gasoline. With little regard for future requirements and with an urgent demand to be supplied, the industry responded by drilling more and more wells

10 H. H. Kaveler, The Engineering Basis for and the Results from the Unit Operation of Oil Pools, (1949) 23 Tulane L. Rev. 331 at 335.

11 I.O.C.C., supra, n. 6, at 37 . 
and exploiting more oil reserves. Dense development and wide-open production of oil from these fields resulted in a flood of oil for a short period at peak rates, followed by rapidly declining production rates. The result has been described rather graphically as a "'grab bag' era of excesses".12

\section{The economic waste}

These, then were the main factors which contributed to over-development by excessive drilling. The cost to the industry was stupendous as can be seen clearly from estimates of the cost of unnecessary ${ }^{13}$ wells drilled even after the advent of spacing regulations due to the vast number of exceptions granted. One writer estimated in 1938 that probably between 4,000 and 5,000 such wells were drilled each year in the United States at a drilling cost between $\$ 80$ million and $\$ 100$ million which was a charge upon the industry of about 10 cents per barrel on a billion-barrel production per year. ${ }^{14}$ The same writer estimated that unnecessary drilling in Texas cost more than $\$ 50$ million per year and that the total cost of unnecessary wells in East Texas alone was $\$ 160$ million. Oklahoma's share of unnecessary drilling, he found, was costing from $\$ 15$ million to $\$ 20$ million annually and, prior to 1937 , probably 1,400 unnecessary wells had been drilled at a total cost of more than $\$ 85$ million. By 1952 another writer estimated that the economic waste resulting from drilling, equipping and operating unnecessary wells in Texas alone had averaged more than $\$ 100$ million each year of the previous five and one-half years. ${ }^{15}$ The cost to the industry prior to the introduction of spacing requirements, considered as a percentage of total industry expenditure at that time, must have been even more incredible.

\section{Production waste}

The extent of the loss in terms other than actual expenditure on drilling can also be estimated from illustrations of field development after the introduction of spacing legislation. The Kettleman Hills field in California contained a very deep pool with a high initial gas pressure. The discovery well was located high on the structure with a high gas-oil ratio. About twenty high-ratio wells were drilled in the discovery area and, it has been said, contributed more to the depletion of reservoir energy than all the other wells in the field. ${ }^{16}$ Six years after discovery in 1930 , a survey disclosed that the average bottom-hole pressure for the entire field had dropped more than one-third. Reservoir pressure had declined as much as a pound and a half per day with the result that by 1938 it was necessary to resort to pumping.

\section{The value of proper spacing}

It must be pointed out, however, that close spacing of wells cannot be blamed alone for these examples of waste. Other matters played a part but regulation of spacing was one of the obvious remedies. Its effectiveness as a conservation measure can be seen from the fact that

12 Id., at 57.

13 i.e., from an engineering point of view.

14 Northcutt Ely, The Conservation of Oil, (1938) 51 Harv. L. Rev. 1209 at 1232 et seq.

15 Robert E. Hardwicke, Oil-Well Spacing'Regulations and Protection of Property Rights in Texas, (1952) 31 Texas L. Rev. 99 at 111 et sea.

16 Northcutt Ely, supra, n. 14, at 1233 . 
in New Mexico some 317 million barrels of reserves were developed in the years 1934, 1935 and 1936 with only 820 wells while in the same period, 288 million barrels were developed in West Texas with 2,346 wells. ${ }^{17}$ A further illustration is the North Burbank Pool in Oklahoma which was discovered in 1923. It was drilled on ten acre spacing over an area of some 23,000 acres and in 1949 had produced (under a belated co-operative gas-injection repressure programme commenced in 1932) about 9,000 barrels per acre. South Burbank, discovered in 1935, and from the beginning unit operated by gas-injection pressure maintenance, was drilled on twenty acre spacing over an area of 2,760 acres. Despite the difference in spacing, this pool too, in 1949, had produced approximately 9,000 barrels to the acre. ${ }^{3 *}$ Wider spacing was not alone responsible for this as the South Burbank field was developed as a unit operation but the example does illustrate the importance of avoiding close spacing. The same rate of recovery per acre was achieved in these two fields despite the fact that the spacing requirements in South Burbank were twice those in the North field.

\section{The first spacing regulations}

It is not surprising then that spacing regulation was included in the first conservation statutes. The first requirement in the U.S. appeared in $1919 .{ }^{19}$ It was passed by the Texas Railroad Commission pursuant to a waste statute that placed the enforcement of conservation measures in the hands of that body. Known as Rule 37, it read as follows:

No well for oil or gas shall hereafter be commenced nearer than three hundred (300) feet to any other completed or drilling well on the same or adjoining tract or farm; and no well shall be drilled nearer than one hundred and fifty (150) feet to any property line; provided, that the Commission, upon petition filed, showing good cause, and provided that no injustice will be done, may after hearing had, upon notice to adjoining tract owners or lessees, allow drilling within shorter distances than as above described. Rule 37 shall not for the present be enforced within the developed and defined oil fields known as the Gulf Coast Fields.

The provision for exceptions was intended primarily to protect the owners of small, narrow or irregularly shaped tracts on which a well could not be drilled more than 150 feet from all boundary lines. As will be seen in discussing spacing requirements in Texas, ${ }^{20}$ the exceptions granted have been numerous and have resulted in a vast quantity of litigation.

\section{Pooling}

So, from this time on, conservation statutes required spacing as a minimum step towards preventing wasteful production. However, the requirement obviously created a problem for the owner of a tract which was smaller than the specified drilling unit. The prohibition against drilling in such a case virtually amounted to confiscation of the oil and gas under the tract owner's land contrary to the due process requirements of the U.S. Constitution. Two remedies were available: to permit exceptions or provide for pooling of interests to form a drilling unit. However, the idea of pooling itself faced difficulties as there was a considerable body of opinion that it violated the anti-trust laws..1 
The answer to this problem was found in enacting legislation authorizing pooling and providing that it would not violate such laws. A further problem which faced pooling was the reluctance of some owners to participate largely due to their ignorance of what was involved. Thus, compulsory pooling was introduced but progress was slow. In 1943, one writer could comment only that "some" statutes had at that time provided for the establishment of drilling units and the pooling of interests. ${ }^{22}$ However, by 1966 another writer could state that almost all of the major oil-producing states had some form of compulsory pooling, the most noticeable exceptions being California and Kansas. ${ }^{23}$

\section{Engineering developments}

Much of this progress in regulation of well spacing naturally must be attributed to developments in petroleum engineering and technology. ${ }^{24}$ The problem of close drilling was one of the first technical aspects of production given general consideration in the industry. ${ }^{25}$ Although spacing is not in itself a technique but a production practice, ${ }^{26}$ its importance was early the subject of technical study. ${ }^{27}$ In 1914, it was pointed out that regional drainage rather than actual thickness of sand probably was responsible for the prolific production from some tracts that were studied. ${ }^{28}$ In the previous year, Huntley had pointed out that "town-lot development and the conditions brought about by many operators with small leases fighting for production result in extravagant and wasteful methods of production".29

However, a controversy over the exact nature of the relationship between the number of wells drilled and the rate of recovery developed and has not completely disappeared even today..$^{30}$

But while opinions may differ as to the effect of intensive drilling where the wells are properly located on the structure and are produced at a minimum rate, there is little dispute as to the adverse result on reservoir pressures where the excessive drilling is at random without respect to reservoir conditions. ${ }^{31}$ Even today, a rigorous quantitative determination of the optimum spacing is not yet possible, although a careful reservoir study can be used with a rather good degree of confidence to select a reasonable well spacing. ${ }^{32}$ The most important contribution of engineering and technological developments has been the realization that ultimate oil recovery from a reservoir is essentially independent of well spacing, provided the wells are spaced with due regard for geometric and stratigraphic configurations of the reservoir and the nature of the producing mechanism. ${ }^{33}$ The capacity of a well to drain "is limited only by sub-surface and not by surface conditions."

22 Leslie Moses, Some Legal and Economic Aspects of Unit Operations of Oil Fields, (1943) 21 Texas L. Rev. 748 at 751 .

$23 \mathrm{~L}$. Proctor Thomas, Prospects for Compulsory Fieldwide Unitization in Texas, (1966) 44 Texas L. Rev. 510.

24 See generaliy, American Petroleum Institute (A.P.I.), History of Petroleum Engineering (1961).

25 Id. at 834 .

26 Id. at 773 .

27 The bibliography on the petroleum industry by De Golyer and Vance contains two and one-half pages of references, in fine type, to the subject of the spacing of wells. See A.P.I., supra, n. 24, at 775 .

28 A.P.I., supra, $n$. 24, at 774, citing from $H$. A. Wheeler, The Illinois Fields.

29 Id., at 774 .

30 Id., at 834-835.

31 Northcutt Ely, supra, n. 14, at 1232.

32 A.P.I., supra, n. 24 at 835-836.

33 Id., at 834.

34 H.' H. Kaveler, supra, n. 10, at 388. 
It is not surprising in view of these developments to find a pronounced trend to wider spacing of oil and gas wells. Increasing numbers of orders provide for 40,80 and 160 acres for oil wells, and 320, 640 acres and even larger spacing for gas wells, due to better knowledge of effective drainage areas and underground migration of oil and gas. ${ }^{35}$ In the U.S. more than 18,000 oil wells were completed in 1965 whereas if 1946 spacing practices had still been in effect then 50 to 100 per cent more oil wells would have been completed in that year. ${ }^{36}$ Indications are that had 1950 practice been applied in 1965 to perform the same drilling and production operations, the estimated cost per barrel of oil produced would have been the equivalent of $\$$ U.S. 0.76 per barrel higher. In addition, the elimination of unnecessary drilling in 1965 through the use of wider well spacing practices provided estimated cost savings ranging from $\$ U . S$. 0.175 to $\$ U . S$. 0.35 per barrel of oil produced. ${ }^{37}$

Obviously, with savings such as these to be gained, the industry has a vested interest in seeing that well spacing regulations comply with its knowledge of production technique. In Canada, the same trend is apparent and this has been largely due to requests from industry. ${ }^{38}$ One result has been that otherwise uneconomic fields have been developed. ${ }^{30}$

\section{TEXAS-RULE 37}

The problems which can arise under spacing regulations are graphically illustrated by a study of spacing in Texas and the Rule 37 cases. $^{40}$ Although the first Rule 37 was promulgated in 1919 pursuant to a waste prevention statute, it was from the outset, concerned also with protection of property rights by mitigating the effects of the Rule of Capture. Thus, as we have seen, ${ }^{41}$ in its first form, the Rule provided an exception so that "no injustice will be done". This was made even more explicit by amendment in 1934 which permitted the Commission to grant exceptions "in order to prevent waste or to prevent confiscation". In all its later forms provision was made in the Rule for exceptions on this ground.

The problem of protecting the owner of the small tract could have been solved by compulsory pooling but provision for this was not introduced in Texas until the enactment of the Texas Mineral Interest Pooling Bill in the early part of 1965 . Mineral owners were reluctant to enter into voluntary pooling agreements due to their lack of understanding of what was involved ${ }^{42}$ and because of the fear of prosecution

85 See the comments in Robert E. Sullivan, Conservation of Oil and Gas, $A$ Legal History (1958), 5-6; I.0.C.C., supra, n. 6, at 60; National Petroleum Council (N.P.C.), Impact of New Technology on the U.S. Petroleum Industry 1946-1965, 14-15, 175.

36 N.P.C., supra, n. 35 , at 14-15, 175 .

37 Id., at 15 .

88 Mobll Oll Canada Ltd., Introduction to Petroleum Reservoir Eingineering, 22.

80 N.P.C., supra, $n .35$ at $14-15,175$. For a discussion of spacing regulation as a factor in decisions by the industry on the economics of development see C. Jackson Grayson, Decisions Under Uncertainty: Drilling Decisions by Oil and Gas Operators (1960).

$129-130$
10 the number of the special rule that regulates spacing. Furthermore, a case involving a spacing rule or order is ordinarily called a Rule 37 case." Robert Hardwicke, supra, n. 15, at 103.

41 Supra, at 361

42 "It may well be asked why the small tracts are not pooled if it is admitted that unlform well spacing is a desirable thing and pooling is a means of accomplishing it. The answer lies in the individual nature of the oil entrepreneurs." A. Allen King, supra, n. 5, at 322. See also Summers, supra, n. 4, \& 83; 34.12. 
for breach of the anti-trust laws, ${ }^{43}$ although it has been said that it is difficult to see how a pooling of interests merely for the purpose of forming a spacing unit could infringe these.t4 Nevertheless, the fear was present and played its part. In the absence of provision for compulsory pooling and faced by a reluctance on the part of mineral owners to pool voluntarily, the Commission resorted to the wholesale granting of exceptions to protect property rights. By 1952, more than 12,500 exceptions had been granted for wells in the East Texas Field alone.

The Commission was encouraged in this practice by the dictum of the Supreme Court of Texas in Brown v. Humble Oil and Refining Company ${ }^{45}$ where it was said that the language of the exception to the rule was used "for the dominant purpose of protecting these property rights ... It guarantees the opportunity in each owner to recover his oil by providing an exception to a uniform spacing regulation that would otherwise prevent him from doing so." ${ }^{13}$ On rehearing, the court said: ${ }^{47}$

[T] he rule and the execption can be so administered as to prevent the invasion of property rights by fairly and reasonably, but of course not exactly, protecting each owner in the ownership of, and in the opportunity to save and produce, the oil and gas which according to the decision in this state he has a right to take.

Numerous cases held that the purpose of the exceptions was to permit each landowner or producer to recover his just and equitable share of the oil and gas in the common source of supply. ${ }^{48}$ Many cases considered the rules to determine the basis on which an exception should be granted. This resulted in what has been aptly described as "wholesale litigation involving Rule $37 "{ }^{49}$ In 1937, from 75 opinions it was possible to isolate 43 distinct holdings directly bearing on the validity of orders granting or denying applications for exceptions. ${ }^{50}$

Although it was the intention of the exception to Rule 37 that small tract owners should not suffer by losing oil or gas to operators on tracts larger than the required spacing unit, in fact the practice of granting exceptions led to the former gaining at the expense of the latter. This was brought about by the Commission favoring the small tract in the assignment of allowables. ${ }^{51}$ Here again, the practice of the Commission was encouraged by at least one judicial decision. In Railroad Commission v. Humble Oil and Refining Co..$^{52}$ the court said that where the voluntary subdivision rule is not applicable the owner of a tract, no matter how small, not only had the right to drill at least one well on the tract "to prevent confiscation", but was also entitled to such an allowable that the well "can be drilled and operated at a reasonable profit." ${ }^{\text {ss }}$ Obviously in many instances this involved the owner of the small tract being permitted to recover more than the amount of recoverable oil and gas in situ beneath his tract. The decision has been considered unsound and contrary to other decisions holding that the

43 Summers, supra, n. 4, $\$ 83$, n. 34.12, citing Hardwicke, Antitrust Laws et al. v. Unit Operation of Oil or Gas Pools, 1948.

14 Robert E. Hardwicke, supra, n. 15, at 101.

45 (1935) 83 S.W. (2d) 935 .

40 Id., at 944 .

47 (1935) 87 S.W. (2d) 1069 , at 1070 .

48 See generally, W. L. Summers, Legal Rights Against Drainage, (1939) 18 Texas L. Rev. 27 , at 33 et seq.

40 Róbert E. Hardwicke, supra, n. 15, at 104. See also Summers, supra, n. 4, $\$ 86$, at 363 et seq.

50 Robert E. Hardwicke, supra, n. 15 , at 104.

51 ld., at 113 et seq.

32 (1946) 193 S.W. (2d) 824.

53 Id., at 832 . 
owner of a tract of land was not entitled to an opportunity to recover more than the amount of recoverable oil and gas in his tract. ${ }^{54}$ Nevertheless, the Commission continued its practice of favouring wells on small tracts in assigning allowable and was not challenged, due in part to the great burden of litigation involving the validity of an allocation order. $^{55}$

These observations on the operation of Rule 37 in Texas illustrate, it is submitted, the difficulties inherent in administration of a spacing regulation more as a means of protecting property rights than as a conservation measure. Property interests must be protected but where this is done in such a manner that the number of wells drilled under exceptions to a spacing rule exceeds that of wells drilled in accordance with the rule, the whole function of spacing as a conservation measure is defeated. What is required is a balance of the two interests which, it will be submitted, is adequately achieved by provisions for voluntary and compulsory pooling. In some instances it may be necessary to sacrifice to a small degree property rights to effect proper conservation and vice versa but in no circumstances should spacing and the assignment of allowables on the basis of spacing areas be deliberately diverted towards favouring the small tract owner. Such an approach is, after all, to take from one to give to the other with no justification. The justification for taking from the small land owner in limited circumstances to in effect give to the owner of the larger tract is that it is a necessary consequence of proper conservation. This has been recognized even in the U.S. with its strict requirements of due process. ${ }^{.6}$

\section{SPACING AS A FUNCTION IN CONSERVATION}

Most of the features of spacing regulations as a function in conservation legislation will be apparent from the earlier discussion of the waste which results from excessive drilling. However, its role in the overall picture of conservation must be considered, as it is but one the means employed in the regulation of drilling for and production of oil and gas. Although proper spacing goes a long way towards reducing high rates of early production at the expense of long-term recovery, it will not achieve the desired result alone. While a well spacing requirement of, for example, 40 acres may be adequate to prevent puncturing of a gas cap and thus preserve the initial reservoir pressure for a time, the natural reservoir energy nevertheless will be depleted at too fast a rate if production from such wells is allowed to proceed uncontrolled. Control of production as well as of drilling is needed to achieve the conservation object of "maximum ultimate recovery and equitable apportionment of the recovery between properties". ${ }^{37}$

Simple spacing requirements preceded proration in most states in the U.S. but did not prove effective in the absence of limits on production. Part of the reason was due to the large number of exceptions which were granted but a further reason was a failure to appreciate that spacing regulation was only one aspect of conservation. Similarly, proration alone was not sufficient for it failed to prorate the investment

54 Robert E. Hardwicke, supra, n. 15 at 117.

55 Id., at 118 et seq.

56 Id., at 105-106.

s7 King, supra, n. 5 , at 312 . 
required to win recovery, being concerned as it was with the recovery itself. ${ }^{58}$

In fact, it has been claimed that possibly more wells were drilled in fields such as East Texas under proration than would have been drilled if the field had run wide open. ${ }^{30}$ This claim was based on the fact that proration was tied to a per well allowance which in many instances favoured the well on a small tract to those on larger tracts. An allocation formula commonly used was the 50-50 formula under the provisions of which one-half of the pool allowable was divided equally among the wells in the pool, regardless of density of wells or the sizes of tracts upon which the wells were located. The other one-half was divided among the wells or tracts on an acreage basis. In certain circumstances a one acre tract would have an allowable of 52 barrels, or 52 barrels per acre, compared with 3.25 barrels per acre to the owner of a full unit of 40 acres when that was the spacing requirement. ${ }^{60}$

From these observations it is apparent that regulation of spacing alone will not achieve proper conservation. Nor will this be achieved by proration of production alone. The desired result is achieved only by a proper operation of the two jointly and not independently of each other. It may be concluded, therefore, that regulation of spacing, while it may be one of the most effective means to conserve oil and gas, is but one factor to be considered in conservation legislation.

\section{POOLING}

As has been seen, spacing regulations inevitably create a problem for the owner of the small tract. One obvious solution was for the owners of such tracts to combine their interests to form a drilling unit and this was done from the earliest days of spacing regulation by contractual arrangement often entered into by the lessee under the authority granted in his original lease. Practically all modern forms of leases contain such a clause authorizing the lessee to pool the leased lands with other lands for the purpose of forming a drilling unit to comply with the local laws. ${ }^{61}$ A further method of complying with the spacing requirements was the community lease whereby several owners joined in a lease which by its terms was a pooling of interests. ${ }^{62}$ However, even in these circumstances there was still a need to resort to pooling agreements where the tract formed by the community lease did not form a spacing unit. ${ }^{63}$ But quite often a lease did not contain authority to pool and in the absence of such authority pooling arrangements could not be entered into voluntarily. ${ }^{04}$

Apart from this difficulty, as we have seen, many landowners were reluctant to agree to a pooling of their interests. If the wholesale granting of exceptions is not to be resorted to, it is therefore necessary to have provision for compulsory pooling if property rights of the small tract owner are to be preserved. As has been said, to deny to the owner of a small or irregular shaped tract the right to drill because of spacing

68 See Northcutt Ely, supra, n. 14, at 1230-31.

89 Id., at 1230 .

60 Robert E. Hardwicke, supra, n. 15, at 113 et seq.

61 See, for example, D. E. Lewis and A. R. Thompson, Canadian Oil and Gas (1959), form A. 1 (b).

62 A. Allen King, supra, n. 5 , at 317 et seq.

63 Id., at 318.

64 Id. 
requirements, without providing a substitute right, denies him the opportunity to recover his "fair share" of the oil and gas in the pool. ${ }^{.5}$ If his rights will not be protected adequately by provisions for voluntary pooling, under which he has no remedy where the owner of the tract with whom he must pool refuses to co-operate, then some provision for compulsory pooling must be included in legislation dealing with spacing. As one writer has said: ${ }^{86}$

If a spacing rule is a good conservation measure, if it is an economic boon in preventing the drilling of unnecessary wells, then it would seem to follow that enforced pooling is necessary.

It has been suggested that this result could be achieved in the absence of specific legislative authority by the granting of permits to drill on condition that the permittee share, on a proper basis stated in the permit, the production from his well with the owner of another tract. ${ }^{67}$ However, such a permit virtually would be a compulsory pooling order and the courts might hold that such power could not rest upon implication. ${ }^{68}$

Most conservation statutes which contain spacing provisions, therefore compel pooling of interests to form a spacing or drilling unit where this cannot be done voluntarily. ${ }^{69}$

The principle is a sound one for, if one well will drain twenty acres, it would be unwise and unnecessary to drill two wells on the 20-acre unit, even if waste prevention did not require control over the number and location of wells. Moreover, even if each tract owner were permitted to drill a well on his small tract, the operation might be unprofitable to one or both of them, for each tract should be assigned its proper allowable, small though it may be.

But, at the same time, compulsion ought not to be introduced where the desired result can be achieved voluntarily and so, most statutes provide for compulsory pooling orders only where the parties are unable to reach a voluntary agreement. The inclusion of provisions for compulsory orders probably encourages parties to pool voluntarily on the basis that, at least by that method, they can decide on their own terms without having these imposed. It is not surprising, therefore, to find that pooling is normally accomplished by voluntary agreement. ${ }^{70}$

\section{UNITIZATION}

Spacing is of course based on property lines and surface measurements. Its shortcoming from the point of view of efficiency is clear from the following statement: ${ }^{71}$

The position of the oil and gas in the pool does not, of course, follow property lines, and therefore to adhere to property lines in their development is to drill unnecessary wells, and to produce oil and gas with the least efficiency.

It was recognized early that the most efficient method of exploiting petroleum and natural gas reserves was by development of a field as a field rather than as a series of small tracts. It has been said that unitization is an idea as old as the science of petroleum engineering. ${ }^{72}$ The idea has been supported by petroleum engineers and conservationists who for years have been calling for legal reforms that would make an entire oil and gas reservoir, rather than the subdivided tracts of

65 I.O.C.C., supra, n. 6, at 181.

66 Myers, supra, $n, 2$, at 270

67 Robert E. Hardwicke, Unitization Statutes: Voluntary Action or Compulsion, (1951) 24

68 Id., at 31 .

70 I.O.C.C., supra, n. 6 , at 60 .

71 Myers, supra, n. 2, at 271. 
land above it, the proper entity for planning and regulation of production. ${ }^{78}$ The advantages were recognized by the 1940 Royal Commission on Alberta's Oil Industry which reported: it

That the ideal Conservation is attained only under unit operation.

That in the absence of unit operation, the compromise measure of Conservation and Proration law must be accepted.

The basic argument in its favour has been given in two statements of fact: ${ }^{75}$

The first is:

Oil found in sub-surface reservoirs is migratory, and for that reason, it constitutes a common source of supply underlying separately-owned tracts which must be divided and shared by the owners of the separate tracts. . . .

The second statement is one derived from modern technology of oil and gas reservoirs, and is proven by experience in the operation of many oil pools. It is: The energy naturally available for production of oil and gas may be conserved, and when necessary, the natural energy may be supplemented by the injection of natural gas or water into the producing reservoir, with the result that twice to three times as much oil can be recovered when it is possible to operate an entire pool as a single lease as compared to what may be recovered by the competitive operation of separately-owned tracts.

Apart from the fact that unit development is based on reservoir conditions rather than surface tracts, its relevance to spacing regulation is that, under unitization, planned deviation from a uniform pattern of well spacing may be both acceptable under a proper allocation system and desirable to prevent drilling unnecessary development wells.

Under unit operation, freedom to locate wells in conformance with the structural characteristics of the reservoir and to utilize fully the reservoir-drive mechanism will permit more efficient recovery with fewer wells. ${ }^{i 6}$

In other words, under unit development there is no need for spacing requirements as wells will be drilled in the most favourable structural position. When a pool is unitized it presents no further problem to any regulatory commission. ${ }^{77}$

\section{HISTORY OF SPACING IN ALBERTA}

In Alberta, although legislative authority was given for the regulation of well spacing in 1926, the first spacing regulation was not promulgated until 1933. In 1926 The Oil and Gas Wells Act ${ }^{78}$ was passed as the first provincial statute to regulate petroleum production. Under that Act, the Lieutenant Governor in Council was empowered to make regulations requiring wells to be licensed, respecting the drilling of wells in road allowances and forbidding drilling within a prescribed distance of roads or road allowances and: ${ }^{70}$

(c) as to the location of oil and gas wells, including the determination of distances between, or offsetting of wells;

No regulations were promulgated under this Act which was repealed and replaced by The Oil and Gas Wells Act $1931 .{ }^{80}$ This Act empowered the Lieutenant Governor in Council to make regulations on matters similar to those dealt with in the previous Act. ${ }^{81}$ The language relating to spacing was changed to the following: ${ }^{82}$

(d) as to the location of the points at which drilling for oil and gas may be done, including the distances between or offsetting of any such points.

73 Id., at 511 .

74 Report of the Royal Commission, at 248. [Emphasis added.]

75 Kaveler, supra, n. 10, at 333-334.

70 I.O.C.C., supra, n. 6, at 60 .

77 Kaveler, supra, n. 10, at 337.

78 S.A. 1926, c. 6.

70 Id., s. 3.

80 S.A. 1931, c. 46.

81 Id., s. 3 .

82 Id., s. 3 (1) (d) 
Regulations were promulgated under this $A c t^{\mathrm{t3}}$ but did not relate directly to spacing apart from prohibiting drilling within thirty feet of the boundaries of road allowances, surveyed roads, railways or other rights of way, dwellings, schools or churches or within three hundred feet of the boundaries of the tract on which the well was located, without the consent of the Minister. ${ }^{84}$ This regulation was obviously aimed at protecting the proprietary rights of neighbouring landowners by requiring that wells not be drilled within the prescribed distance of boundaries. However, it was not a spacing regulation in the sense of requiring a specified distance between wells or that wells be drilled on a specified area. As many wells as the operator wished could be drilled as close to each other on the one tract as the operator thought desirable.

In 1933 Section 9 was amended to give the Province its first spacing requirement. ${ }^{85}$ It read:

No person shall drill, bore or sink any well within 400 feet of any other well,

provided, however, that the Minister may extend or reduce the aforesaid

distance, if in his opinion it is proper, convenient or in the public interest so to do. The amendment was effective from 26th May, $1933 .{ }^{86}$

In 1939 these Regulations were repealed and replaced by the first comprehensive regulatory control of spacing. ${ }^{8 \overline{7}}$ It was provided that no licence should be issued for any well within 440 yards of any drilling or producing well. ${ }^{88}$ However, the Board was authorized to designate parts of the Province in which wells could be drilled at points closer than 440 yards but so that the drainage area for each well should be as nearly as possible forty acres. ${ }^{\text {"0 }}$ In other parts of the Province, the Board was permitted to issue a licence for the drilling of a well within a lesser distance of another well in the following cases: ${ }^{90}$

(i) Where, in the opinion of the Board the surface and subsurface conditions are such that it is not practicable to drill the well so as to be at least $\mathbf{4 4 0}$ yards from any other producing well;

(ii) Where the equipment to drill at a point at least 440 yards from a producing well would prevent the applicant from exercising his right to drill one well in respect of each legal subdivision in respect of which he has the right to search for, win and get petroleum and withdraw gas; and

(iii) In case the applicant's right as aforesaid relates to one parcel only which is less than one legal subdivision and he has no such rights in respect of any other land contiguous or adjacent thereto; and in any such case the Board may issue a license for the drilling of the well at any point designated by the Board, regardless of the distance from such point to the nearest producing well.

A limit was also imposed on the drilling of wells within 330 feet of boundaries except where special circumstances existed which in the opinion of the Board justified a well within a lesser distance. ${ }^{01}$ The Regulations also introduced comprehensive provisions relating to wells which deviated from the vertical or were completed within a certain distance of boundaries measured by projection to the surface thus initiating the concept of a target area." These regulations therefore introduced the basic scheme of spacing requirements in Alberta-a general

\footnotetext{
83 O.C. 769-31.

84 Id.. 8.9.

85 O.C. $465-33$

86 Id.

87 O.C. 45-39.

88 Id., s. $7(1)$.

89 Id., s. $7(2)$

00 Id., s. 7 (3)

01 Id., s. 7(5).
} 
spacing area with penalties for off-target wells and power in the Board to grant exceptions.

A new Section 7 was introduced into these Regulations in $1941,{ }^{\text {, }}$ which extended the prohibition to the drilling of wells within 440 yards of the surface location of any reasonably presumptive future well..$^{04}$ These Regulations also required the drilling of wells as nearly in the centre of the area assigned to the well as conditions permitted.95 The Board was again given authority to grant exceptions although restrictions on its jurisdiction in this respect were removed by a further amendment later the same year which authorized the Board to prescribe locations at distances less than 440 yards distant from one another whenever in its opinion it was proper so to do. ${ }^{.6}$

The Oil and Gas Wells Act 1931 was repealed and renacted in 1942 and again authorized the promulgation of spacing regulations. ${ }^{97}$ Administration of such regulations had been entrusted meantime to the Board established under The Oil and Gas Resources Conservation Act $1938^{\circ 8}$ which itself stated its purpose to be to effect conservation of oil and resources by, inter alia, "restriction or prohibition and whether generally or with respect to any specified area or any specified well or wells."90 This statement of objects was replaced in 1949 by a section which declared one of the objects of the Act to be "to give each owner the opportunity of obtaining his just and equitable share of the production of any pool". 100

Meanwhile, further amendments to the 1941 Regulations had been made in 1947.101 The general spacing requirement was to be one well to every 40 acres and in surveyed territory one well to every legal subdivision. ${ }^{102}$ The Board was empowered to prescribe different spacing units for different producing horizons. ${ }^{103}$ In 1949 the first definition of a "spacing unit" was introduced and included all subsurface areas bounded by the vertical planes in which the surface boundaries lay. ${ }^{104}$ At the same time it was provided that, in order to qualify for a production allowable based upon the 40-acre spacing unit, every well had to be completed within a target area. ${ }^{105}$ Penalties for off-target completion were provided and the Board was empowered to specify the target area for wells drilled under exceptions as well as the area to be used as a factor in determining the production allowable for wells completed outside such targets. ${ }^{100}$

In 1950, the The Oil and Gas Wells Act and The Oil and Gas Resources Conservation Act were repealed and their provisions combined in The Oil and Gas Resources Conservation Act 1950. ${ }^{107}$ The intent and purpose of this Act were declared to be to effect conservation of

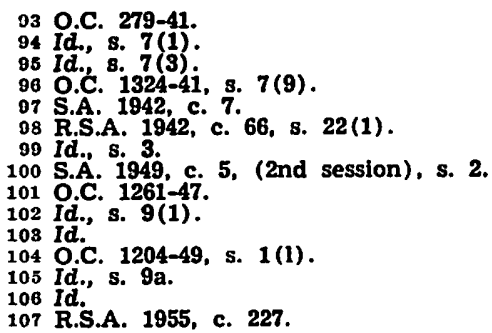


oil and gas, to regulate drilling of wells and to give to each owner the opportunity of obtaining his just and equitable share of the production of any pool. ${ }^{108}$ No well was to be drilled without a licence nor elsewhere than at the point specified in the licence. ${ }^{109} \mathrm{~A}$ general power of regulation was granted to the Board with the approval of the Lieutenant Governor in Council. ${ }^{110}$ Previously the power had been vested in the Lieutenant Governor in Council on the recommendation of the Board. Certain specific regulatory powers relating to spacing were given by Section 30 and the Board was also empowered to designate the area to be allocated to a well in connection with fixing allowable production $^{111}$ whereas previously such area had been tied to the spacing area.

Under this Act, comprehensive regulations were promulgated by the Board in 1950.112 These provided that the spacing unit in surveyed territory should be one legal subdivision and elsewhere an approximately square area of 40 acres. $^{113}$ By amendment in 1952, separate spacing units were introduced for oil and gas wells. ${ }^{114}$ The area for an oil well remained the same ${ }^{11:}$ but for a gas well was to be one section in surveyed territory and elsewhere an approximately square area of 640 acres situated so as to comprise land which, if surveyed, would be within a section. ${ }^{116}$ The Board was empowered to prescribe a spacing unit of any size or shape or within any boundaries where in its opinion it was proper to do so. ${ }^{117}$ Separate target areas for oil and gas wells were introduced. ${ }^{118}$

In 1957, The Oil and Gas Resources Conservation Act 1950 was repealed and replaced by The Oil and Gas Conservation Act $1957^{119}$ which has since been replaced by The Oil and Gas Conservation Act 1969. ${ }^{120}$ However, before turning to a consideration of the present position, it is proposed to consider the Regulations promulgated under the 1957 Act and the amendments thereto. The 1957 Drilling and Production Regulations ${ }^{121}$ provided that the normal spacing unit for oil was to be one legal subdivision in that part of the Province lying east of the fifth meridian ${ }^{122}$ and elsewhere, two legal subdivisions comprising either the east or west half of a quarter section. ${ }^{123}$ The normal spacing unit for a gas well was to be one section. ${ }^{124}$ The Board was empowered to prescribe spacing units other than normal spacing units or such special spacing units as may be proper in individual cases. ${ }^{125}$ Power was also given to consider each production zone separately. ${ }^{128}$ Detailed provisions relating to target areas and determination of allowables were in-

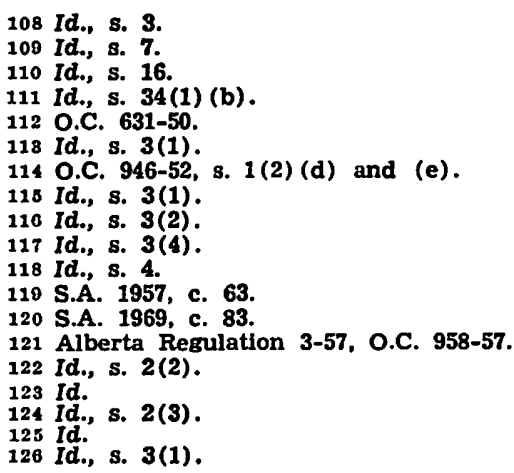


cluded. ${ }^{127}$ Spacing requirements could be varied for wells drilled in pools that were unitized. ${ }^{128}$

The spacing units for oil were increased in 1962 by providing for a unit of two legal subdivisions in that part of the Province west of the fifth meridian and south of the north boundary of township 59 and of one quarter section in that part west of the fifth meridian and north of the north boundary of township 59.129 Later that year the quarter section requirement was extended to the whole Province ${ }^{130}$ In 1964, definitions of "drilling spacing unit" and "production spacing unit" were introduced." "Target area" was defined to mean the part of a spacing unit within which a well could be completed without reduction of its allowable because of its location. ${ }^{132}$

\section{CURRENT SPACING IN ALBERTA:}

Current spacing requirements in Alberta are found in the provinces of The Oil and Gas Conservation Act $1969^{133}$ and in The Oil and Gas Conservation Regulations $1969 .{ }^{134}$ The Act includes in the definition of "wasteful operations" the locating or spacing, inter alia, of wells in a manner that results or tends to result in reducing the quantity of oil or gas ultimately recoverable from a pool "under sound engineering and economic principles". ${ }^{135}$ The definition also includes the location of a well in a manner which causes excessive surface loss and the inefficient, excessive or improper use or dissipation of reservoir energy. ${ }^{130}$ The intent and purpose of the Act include securing the observance of safe and efficient practices in the location and spacing of wells. ${ }^{137}$ As in previous legislation, no well is to be drilled without a licence and then only at the location specified therein. ${ }^{13 s}$ The Board is empowered to make regulations prescribing normal drilling spacing units and providing for the establishment of other drilling spacing units. ${ }^{139}$ Production spacing units are also to be established by regulation. ${ }^{140}$

Under the 1969 regulations, which substantially re-enact the detailed regulations which became effective as from January $1,1968,{ }^{141}$ so far as spacing is concerned, the normal drilling spacing unit for an oil well is one quarter section and for a gas well one section. ${ }^{142}$ The Board may, after a public hearing or after publication of notice, prescribe special spacing units which may differ in size, shape or target area but the normal unit will not be reduced unless the applicant shows that: ${ }^{143}$

(a) improved recovery will be obtained, or

(b) additional wells are necessary to provide capacity to drain the pool at a reasonable rate without exceeding the maximum rate limitation established for wells in the pool, or

127 Id., s. 6 and s. 7.

128 Id., s. 8. 8 Alberta Regulation $39-62$, O.C. 89-62, s. 2.

130 Alberta Regulation 133-62, O.C. $337-62$, s. 2 and s. 3.

131 Alberta Regulation 629-64, O.C. 1940-64, s. 2.

132 Id.

133 S.A. 1969, c. 83.

134 Alberta Regulation 183-69.

135 S.A. 1969, c. 83, S. 2 (1) (45)

186 Id.

137 Id., s. 5.

138 Id., s. 23

139 Id., s. $22(1)$ (6)

140 Id.. s. $22(1)$ (8).

141 Alberta Regulation 467-67, O.C. 2314-67.

142 Alberta Regulation 183-69, O.C. s. $300 a$.

143 Id., s. 301. 
(c) the drilling spacing units would be in a pool in a substantial part of which there are drilling spacing units of such reduced size, or

(d) in a gas field, increased deliverability is desirable,

and that it does not appear that the reduced drilling spacing units will preclude economic development for the area of application and the majority of wells in the pool are part of the pool.

Where local geologic, topographic or other conditions require, the Board may order that a well be deemed to be completed within its target area. ${ }^{14}$ Where a well is completed within its target area, its base allowable shall not be reduced because of its location. ${ }^{145}$ One or more drilling spacing units may be established as a production spacing unit ${ }^{14:}$ but shall include only laterally adjoining drilling units ${ }^{14 i}$ and shall not exceed 2.25 sections for an oil well. ${ }^{148}$ Otherwise, the production spacing unit of a well shall be its drilling spacing unit and shall have only one producing well. ${ }^{140}$ Production spacing units may be of varied shape but shall not encircle an area that is not included in any unit. ${ }^{150}$

It is to be noted that these Regulations do not specifically refer to exceptions to normal spacing units being granted to protect property rights, although the Board is empowered to make regulations "as to the location of wells . . . for any purpose including . . . the protection of ... property ...".151 The obvious question is whether adequate protection is provided for the owner of a tract smaller than the required spacing unit for, as we have seen, this is one of the objects of spacing regulation. Although the Regulations are directed towards what appear to be purely conservation ends, it is submitted that adequate protection of property rights is provided by the inclusion in the legislation of provisions for compulsory pooling. Under the Act, the Board is to encourage efforts initiated by owners of oil and gas interests to consolidate their interests "for the purpose of accomplishing the more efficient and more economical development and production of the oil and gas resources of the pool. ..."152 Where an agreement to operate tracts as a unit cannot be made on reasonable terms, the owner of a tract within a drilling spacing unit may apply to the Board for an order that all tracts within the unit be operated as a unit. ${ }^{153}$ It is submitted that these provisions adequately protect the proprietary interests of small tract owners. ${ }^{154}$ They are more effective than the practice of granting exceptions to the owners of tracts less than the required unit as they permit adherence to spacing requirements based on more enlightened knowledge of reservoir characteristics. The provisions for exceptions for particular fields or areas permit sufficient flexibility for the pecularities of particular reservoirs to be taken into account so that excessive drilling does not occur in some fields and the development of other fields is not prevented by spacing requirements which may be too large to allow economical de-

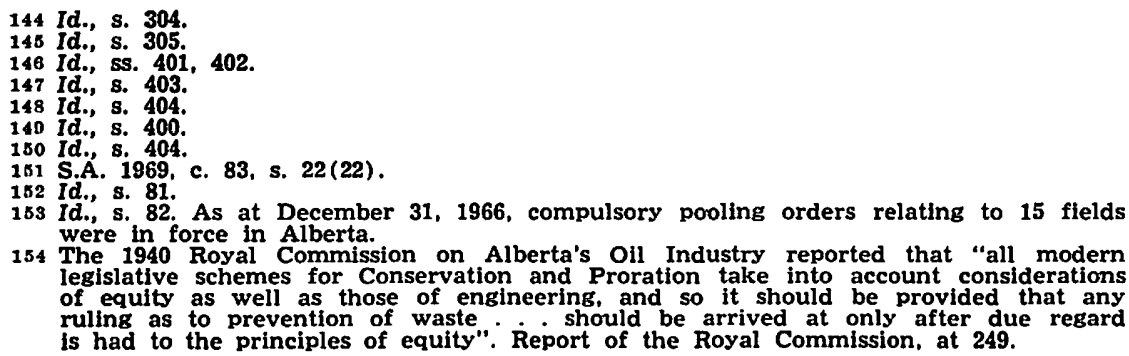
legislative schemes for Conservation and Proration take into account considerations of equity as well as those of engineering, and so it should be provided that any ruling as to prevention of waste. . should be arrived at only after due regard is had to the principles of equity". Report of the Royal Commission, at 249. 
velopment. ${ }^{15 s}$ It is submitted, therefore, that these Regulations meet the requirements of proper well spacing which have been stated as follows: ${ }^{150}$

Proper well spacing and the size of the spacing units depend on the characteristics of each pool, and logically should be left to the determination of the regulatory agency after notice and hearing rather than being fixed by statute. Experience has shown that frequently the statutory limitation is wrong, and there is unfortunate delay in effecting a change.

It may be noted in conclusion of this part that Canadian legislation has not given rise to the vast amount of litigation which has attended spacing requirements in the U.S. This is probably due to the fact that provisions for compulsory pooling have been included in the legislation and also the fact that, the question of protection of property rights does not arise as frequently where there is little freehold land. Another reason may be the settlement pattern which has tended to define surface ownership in terms of sections, half-sections and quarter-sections with the result that 40,80 and 160 acre spacing patterns fit into the surface ownership pattern. Whatever the explanation, a search has not revealed a single Canadian decision dealing with the grounds on which exceptions to spacing requirements should be granted.

\section{CONCLUSIONS}

Spacing requirements clearly have evolved in the light of increased knowledge of petroleum reservoir characteristics. It can be reasonably expected that further experience and improved knowledge of petroleum reservoirs will bring about more improvement in conservation regulation and practices. ${ }^{157}$ But, for this to be achieved, the petroleum engineer and lawyer must work together, "the engineer to determine what causes waste and how to prevent it, the lawyer to determine how that can legally be brought about and give protection to property rights". ${ }^{158}$ Much has been achieved in the field so that generally speaking spacing requirements conform to the following statement of objects by the Interstate Oil Compact Commission: ${ }^{150}$

Spacing patterns for wells in a pool or reservoir to prevent waste, to contribute to orderly development, and to protect property rights, should be determined with full cognizance of the following points:

(1) The distance between wells should not be so close as to endanger other wells and property if a blowout or fire occurs.

(2) The location of wells usually should provide for a relatively uniform spacing pattern under diversified ownership conditions, and prevent crowding of property lines.

(3) Location of wells may be regulated by providing minimum distances between wells and lease lines, or by providing for spacing units, with flexibility to space wells at distances greater than the authorized minimum.

(4) The spacing pattern or the size of the spacing unit preferably should be such that the area attributed to each well will not be less than the approximate maximum area that can be drained economically and efficiently by one well.

(5) The spacing unit normally is the same as the proration unit, which is the area attributable to a well for the purpose of allocating allowable production. The allowable should not be increased merely because one or
more wells are permitted to be completed on the unit in addition to the one well than can economically and efficiently produce the recoverable oil and gas in the unit.

$155 \mathrm{As}$ at December 31, 1966, 238 special spacing orders were in force. These orders were exempted from filing as from that date by Alberta Regulation 454-67, 0.C. 2266-67.

156 I.O.C.C., supra, n. 6, at 181 .

157 A.P.I., supra, n. 24, at 1152.

158 Id.

159 I.O.C.C., supra, n. 6, at 57. 
However, even where spacing requirements satisfy these objectives, they still suffer from the basic defect that oil and gas reservoirs do not follow property lines. The answer to this problem is to be found in compulsory fieldwide unitization.

Compulsory fieldwide unitisation is not a cure-all for the oil industry. It does, however, promise use of the best known scientific methods to produce the most oil from a single reservoir at the lowest possible cost.100

Under unitization the need for production spacing regulations virtually disappears as wells will only be drilled where they are needed to produce the reservoir with the most efficiency. This practice obviously should not be prevented by legislation which is aimed at conservation. The need to protect property rights disappears because there are no property lines under a scheme of unitization. The two basic reasons for spacing regulations no longer exist. It may be said that spacing regulations would still be needed for drilling, as opposed to producing, operations but obviously the industry would not, as a matter of economics, drill more exploratory wells than necessary and if they are necessary to discover new reserves then they should not be prohibited.

It is submitted that with compulsory fieldwide unitization ${ }^{161}$ there is no need for spacing regulations. The risk of early over-exploitation can be adequately met by limiting production to maximum efficient recovery rates which need not depend on any surface area factor under unitization.

160 L. Proctor Thomas, supra, n. 23, at 531.

101 The Oil and Gas Conservation Act, S.A. 1969, c. 83 contains provisions for compulsory unitization (s. 87 to s. 95 ) which have not been proclaimed. 